\title{
Surprises in a Growing Market Niche: An Evaluation of the German Private Life Annuities Market
}

\author{
by Hans-Martin von Gaudecker and Carsten Weber*
}

\begin{abstract}
High replacement rates from public old age insurance might lead to the belief that little room is left for private sector life annuities in Germany. Taking a closer look, we find a small market with a surprisingly large variety of products. Due to the recent pension reform and future ones to come the market is projected to grow substantially in the years to come. This paper describes the life annuity contracts available and determines their money's worth for different subgroups of the population.
\end{abstract}

\section{Introduction}

Life annuities generate a life-long income stream in return for a premium paid to an insurance company. In their simplest form they provide protection against the risk of outliving one's resources by pooling the assets of persons with similar life expectancies when longevity is uncertain. They are viewed as the most important decumulation device in private defined contribution schemes. In Germany, tax relief for third pillar savings introduced by the 2001 pension reform is only granted if a specified fraction is annuitized no later than at the age of 85 .

Markets for life annuities all over the world are smaller than suggested by predictions from economic theory. ${ }^{1}$ The literature proposes several explanations for this phenomenon. Wherever applicable, crowding out due to public defined benefit systems is probably the most important reason. In a sense, payments from these schemes can be viewed as life annuities. Other possibilities include: adverse selection if consumers are better informed about their survival probabilities than insurers; loss of liquidity; unwillingness to surrender one's capital to an insurance company due to psychological reasons or stemming from a bequest motive; and administrative loads or possible mark-ups from providers. ${ }^{2}$ Some of these may lead to the assertion that life annuities include high load factors from the perspective of the consumer. A load factor is any difference between the premium charged by an insurer and the premium that would have to be paid for a hypothetical actuarially fair life annuity. In our later discussion, we define it to be one minus the money's worth ratio.

* Hans-Martin von Gaudecker is based at the Mannheim Research Institute for the Economics of Ageing, Department of Economics, University of Mannheim; and Carsten Weber is based at the Institute of Insurance Science and Department of Business Administration, University of Mannheim. We would like to thank Axel Börsch-Supan and Anette Reil-Held for suggesting this paper and many helpful comments; the latter also applies fully to Peter Albrecht and Alexander Ludwig. Finally we appreciate data provision by Thomas Lueg from GDV. Any remaining flaws are the authors' sole responsibility.

1 See Mitchell and McCarthy (2002) for an overview.

2 See for example James and Vittas (2001). 
The most popular approach to estimating these load factors has been pioneered by Warshawsky (1988). He defines the money's worth ratio ("MWR") as the expected discounted present value of all future payments from the annuity contract, divided by the premium payment and calculates its values for the U.S. market. The difference between the MWR and one is the proportional loading charge as perceived by the consumer. Mitchell et al. (1999) refine this concept and use more recent data for the U.S. They also extend the analysis into several directions, for example they incorporate taxes and calculate the insurance value of life annuities for a class of CRRA utility functions. James and Vittas (2001) apply the money's worth methodology to several countries and discuss policy implications which emerge from international experiences. Mitchell and McCarthy (2002) review this literature in the light of worldwide demographic change and supply discussions of various annuities-related topics, such as differential mortality and regulatory issues.

To our knowledge, such an analysis has not yet been carried out for Germany. Public old age benefits have traditionally been very high, but they are projected to decline and the need for private provision of old age security will rise. This paper addresses the question of whether the German life annuities market is prepared to provide reasonable substitutes for public payments in terms of product types and load factors. Our findings are encouraging. Despite its small size, a wide variety of life annuity products exists. The MWR ranges between 0.65 and 1.1 depending on the assumptions one is ready to make. Our preferred assumptions yield an approximate value of 0.95 , which fits in well with international comparisons. Furthermore, specifically elaborated mortality tables are an important prerequisite for the functioning of life annuities markets. These exist for Germany but they will need improvement in the future.

This paper is organized as follows. Section 2 attempts to sketch the current size of the German life annuities market and describes the expectations regarding its future development. Section 3 characterizes the products available in the market and points out the ones which are analysed later on. Section 4 contains a description of the mortality tables commonly used by insurance companies. In section 5 we determine the money's worth of commonly available life annuities and present some comparative statistics as well as a comparison with international findings. Conclusions are drawn in the last section.

\section{Market overview}

This section attempts to outline the size of the German life annuities market. Data are scarce due to its relatively small size compared to other insurance markets. We use publications from the Association of German Insurance Companies (Gesamtverband der deutschen Versicherungswirtschaft, "GDV"), which includes virtually all commercial insurers in the period from 1998 to 2001 . The data are aggregated at a level which includes some minor figures that do not fit well with our definition of life annuities, for example disability insurance and long-term care insurance. The figures shown are thus higher than true values but they should be reasonably close to them.

Table 1 shows the payouts from life annuities as compared to payments made from the public old age insurance system, which are the major source of income during retirement in Germany. Their importance is still small, rising from a level of 1 per cent in 1998 to 1.5 per cent in 2001. Total payouts amounted to $€ 2,735$ million in 2001, a rise of about 58 per cent in a three-year period. Future increases are projected to be even higher. First, reductions of public pension payments are likely to generate a new demand for private pension plans. 
Table 1:

Private annuities and public pensions between 1998 and 2001

\begin{tabular}{|c|c|c|c|c|c|c|c|}
\hline Year & $\begin{array}{c}1 \\
\text { Life } \\
\text { annuities } \\
\text { paid by } \\
\text { insurers } \\
€ \text { million }\end{array}$ & $\begin{array}{c}2 \\
\text { Main } \\
\text { insurance } \\
\text { benefits } \\
\text { paid by } \\
\text { insurers } \\
€ \text { million }\end{array}$ & $\begin{array}{c}3 \\
\text { Payments } \\
\text { from } \\
\text { public old } \\
\text { age } \\
\text { insurance } \\
€ \text { million }\end{array}$ & $\begin{array}{c}\text { Growth } \\
\text { rate } \\
\text { annuities }\end{array}$ & $\begin{array}{c}\text { Ratio } \\
1 / 2\end{array}$ & $\begin{array}{c}\text { Ratio } \\
1 / 3\end{array}$ & $\begin{array}{c}\text { Ratio } \\
2 / 3\end{array}$ \\
\hline $\begin{array}{l}1998 \\
1999 \\
2000 \\
2001\end{array}$ & $\begin{array}{l}1,732 \\
2,053 \\
2,457 \\
2,735\end{array}$ & $\begin{array}{l}25,841 \\
29,402 \\
32,804 \\
35,429\end{array}$ & $\begin{array}{l}171,512 \\
167,782 \\
177,758 \\
183,393\end{array}$ & $\begin{array}{l}18.5 \% \\
19.7 \% \\
11.3 \%\end{array}$ & $\begin{array}{l}6.7 \% \\
7.0 \% \\
7.5 \% \\
7.7 \%\end{array}$ & $\begin{array}{l}1.0 \% \\
1.2 \% \\
1.4 \% \\
1.5 \%\end{array}$ & $\begin{array}{l}15,1 \% \\
17,5 \% \\
18,5 \% \\
19,3 \%\end{array}$ \\
\hline $\begin{array}{l}\text { Increase } \\
1998-2001 \\
\text { Average annual } \\
\text { increase }\end{array}$ & $57.9 \%$ & $37.1 \%$ & $6.9 \%$ & & & & \\
\hline
\end{tabular}

Source: GDV, Statistical Yearbooks of German Insurance 2002, 2001, 2000.

Note: "Main insurance contracts" denotes life insurance contracts, private old age insurance, and some minor positions. They are so called because they may include additional options such as invalidity insurance, which are not included in these figures.

Second, the 2001 pension reform has created tax incentives to invest in private pension plans which include mandatory annuitization no later than at the age of $85 .^{3}$

Unfortunately, no figures on the accumulation side of private old age provision by means of life annuity contracts are available. The reason for this is the aggregation level of the data: most products of German life insurers serve different purposes and we are not able to isolate the ones of interest to us. Consider for example an endowment policy which facilitates both annuitization and lump sum withdrawal of the accumulated stock. In order to analyse these figures we would need the share of policies being annuitized, which is not available.

\section{Product overview}

Despite its relatively small size a wide variety of contracts are offered in the German life annuities market. Sections 3 and 5 draw upon the data base "LV-Win" from Morgen \& Morgen $\mathrm{GmbH}$, Hofheim am Taunus. It is a standard product used by brokers to make offers to their clients. Thus insurance companies have a strong interest in the correct representation of their products and fees. The sample contains 80 companies and covers about 95 per cent

\footnotetext{
3 Quoted from Schnabel (2002), where a detailed analysis of future prospects of the German annuities market can be found.
} 
of the market. It does not include any group insurance ("Kollektivversicherungen"), e.g. through employer-sponsored pension plans.

For the contracts under consideration, we are not able to link offers with sales. This would be most interesting because we find large differences in both product design and prices, which might be inconsistent with rational informed consumer behaviour. Exploring their actual purchasing patterns could provide some important insights. However, the data are sufficient to evaluate the money's worth of individual life annuities. Extending the typology of Poterba (1997), we first organize the products along the following lines.

\section{Method of paying premiums}

The two predominant forms in this category are fixed annual and single premiums ("Rentenversicherung gegen laufende Beiträge" /"RV gegen Einmalzahlung"). We do not have information on the availability of more flexible contribution schemes. Our focus in the analysis below is on single premium life annuities, for reasons that will be given in the next paragraph.

\section{Waiting period}

Contracts with zero and positive waiting periods should be distinguished in an analysis. Nonetheless our focus on single premium immediate life annuities ("SPIAs", "sofortbeginnende RV gegen Einmalzahlung") is quite general because most deferred life annuities ("aufgeschobene RV") contain a refund option during accumulation. ${ }^{4}$ In this case, a person approaching retirement age faces exactly the same choice regarding annuitization as someone who accumulated stock in a different investment object. Consequently, such a contract can be divided into two different components, the first one being an accumulation vehicle, the second one being a SPIA. For our purposes only the latter part is of interest.

\section{Number of lives insured}

An individual life annuity pays benefits to the recipient until the time of death. In case of a joint life annuity, payments continue as long as any of the insured persons are alive. With very few exceptions, only individual contracts are offered on the German market. However, depending on the above contract characteristics some 65 to 78 per cent of the companies offer supplementary survivorship insurance ("Hinterbliebenenzusatzversicherung") which has the same implications as a joint life annuity. We consider only individual contracts as neither data on prices for survivor policies nor joint mortality tables are available.

\section{Nature of payouts}

We consider period life annuities ("RV mit Garantiezeit") and life annuities without refund ("RV ohne Beitragsrückgewähr"). In the first case benefits are paid during a fixed number of years regardless of the death of the annuitant. If he dies before the end of the fixed

\footnotetext{
4 This is true for 96 per cent of the contracts offered on the market with fixed annual premiums and 86 per cent of single premium deferred annuities.
} 
payment period, the benefits are paid to his beneficiaries until its end. Period life annuities are more popular than regular ones. The longest possible guaranteed payment period depends on the entry age, with no guaranteed payment possible beyond the age of 80 . We include periods of $0,5,10,15$, and 20 years, although we report only results on the zero and the ten-year period-certain contracts.

Roughly one-third of the companies offer contracts with a refund option during the decumulation phase. We do not consider these products for reasons of clarity.

\section{Allocation of investment and inflation risk}

Three combinations are possible in this case. Real life annuities assign both risks to the insurer. He bears only the investment risk if the annuity is paid on a nominal basis and none of the two if a variable annuity is considered. ${ }^{5}$ We could not detect any real life annuities offered on the German market. There exists a small but growing market of pure variable life annuities ("fondsgebundene RV"). Their money's worth will depend in large part on the future returns on the underlying investment vehicle. ${ }^{6}$ Although we will face a similar problem when evaluating standard German life annuity contracts, it is less important there. We do not consider variable life annuities in our analysis.

The standard product in Germany is a participating life annuity. It contains a nominal guaranteed life annuity and a variable part which depends on the surplus of the company. ${ }^{7}$ Law restricts the maximum interest rate insurers can use to calculate the guaranteed part of the annuity to 3.25 per cent. $^{8}$ It further requires firms to apply mortality tables and costs valid on the date when the contract was signed. The nominal guaranteed life annuity is calculated on this basis. Capital gains or losses on the annuitants' assets relative to this rate as well as deviations of realized mortality from expected mortality and administrative costs enter the surplus of the company. If positive, at least 90 per cent of the capital gains have to be paid out to the insured within five years. ${ }^{9}$ On the basis of their surplus, companies calculate the profit-sharing rate ("Überschussbeteiligung"). Subtracting the guaranteed rate of generally 3.25 per cent and multiplying this by the initial premium payment yields the variable, or participating, component of the annuity.

\section{Type of participation}

The two polar forms of participation are constant and escalating schemes ("Konstante Rente" and "Dynamische Rente"). Most companies also offer mixed forms ("Teildynamische Rente"). If participation of the constant type is chosen, each year an amount depending on the premium payment and the profit-sharing rate is added to the guaranteed part. With the escalating annuity option the participation component is annuitized, yielding a yearly rise of the guaranteed pension payment. This annual growth rate ("Dynamisier-

\footnotetext{
5 One might argue that a variable annuity provides a hedge against inflation. In our case the validity of the Fisher effect is not required, as we do not include inflation in the analysis.

${ }^{6}$ For a description of the mechanics of variable annuities, see Poterba (1997).

7 The following description of the German participation scheme is a gross simplification. For details on the system, see for example Schierenbeck and Hölscher (1998).

${ }^{8}$ In 2004, this number will drop to 2.75 per cent.

9 The 90 per cent split is due to German insurance law, the five-year period due to tax law. See Schierenbeck and Hölscher (1998), p. $733 \mathrm{ff}$.
} 
ungsfaktor") equals approximately the profit-sharing rate less the guaranteed interest rate of usually 3.25 per cent.

Throughout the last 25 years variations in the profit-sharing rate have been very low compared to capital market fluctuations: German insurance companies follow a strategy of smoothing surplus over time. Tax law facilitates this by allowing hidden reserves in the balance sheet. Additionally, high periodic surpluses can be used to build up reserves which have to be distributed in the course of up to five years. Albrecht and Maurer (2002) consider the net investment returns of insurers on a book value basis. Since this is the predominant and most volatile component of the surplus (minor ones being gains or losses from actual over expected mortality and costs) this is a reasonable proxy for profit-sharing rates. Average net investment returns ranged between 6.85 per cent and 7.5 per cent during the period from 1980 to 1998 for the 30 largest insurers. ${ }^{10}$ More recently, profit-sharing rates declined slightly to a 2002 average of 6.17 per cent. In 2003 they experienced another drop to the current 4.8 per cent ${ }^{11}$ which represents an all-time low, although projections for 2004 are even lower. These figures contain the guaranteed interest rate of 3.25 per cent. Figure 1 shows the average participation rate and compares it with the current term structure of interest rates.

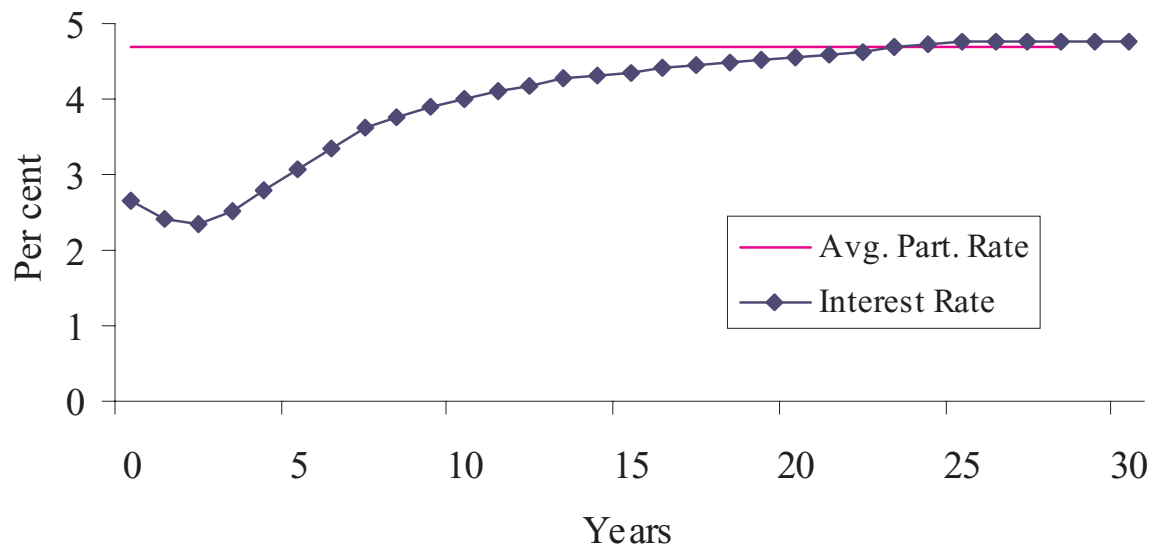

Figure 1: Interest rate and average participation rate 2003 (= growth rate annuities + $3.25 \%$ )

Note: Average profit-sharing rates calculated from growth rates as provided in LV-Win by Morgen \& Morgen GmbH. Interest rates are taken from ECB monthly bulletin, March 2003 and http://www.bondboard.de/.

10 Albrecht and Maurer (2002).

11 Average profit-sharing rates refer to all firms in the market and were provided by Morgen \& Morgen 


\section{Mortality tables}

This section illustrates some rather technical details regarding the mortality tables available in Germany. It contains additional information which is not essential for understanding the money's worth concept in the succeeding section and might be skipped. We follow the calculation of tables provided by the German Actuaries' Society (Deutsche Aktuarvereinigung, "DAV"), labelled DAV 1994 R. To our knowledge these provide the calculation base for most insurance companies when dealing with life annuities. Some large insurers are known to construct their own tables while small companies lack the sufficient database to do so. In the following we try to outline the method of construction as done in Schmithals and Schütz (1995). They consider five steps to construct the annuitant mortality tables:

Estimation of the trend function: Census data from 1870 to 1987 are used to obtain a log-linear regression function. In the recent past, sharper declines in old age mortality than before are detected. In order to take this into account, a multiplicative bonus in old age mortality improvements is incorporated into the trend function. This results in a constant mortality decline over time for each age group. Trend functions differ by sex but are assumed to be identical for annuitants and members of the general population.

Construction of period tables: Using the trend function, a period table obtained from census data is projected into each future year under consideration. Additionally, a smoothing algorithm is applied and the tables are extrapolated to cover mortality until age 110 because census tables end at age 89 .

Construction of cohort tables: In order to obtain cohort mortality, a generation is "followed" through the period tables. The resulting tables are often referred to as twodimensional tables.

Mortality tables for the insured population: With data from 1967 to 1992 from six life insurance companies, the relative mortality of insured persons to the general population is calculated, depending on sex and age. Consistent with adverse selection a lower mortality of annuitants is detected.

Further reduction of mortality: In order to reflect actuarial conservativeness, the final DAV 1994R tables contain an arbitrary further reduction of mortality. This fifth step is irrelevant for us because it has nothing to do with actual mortality.

McCarthy and Mitchell (2001) provide some metrics for comparing mortality tables, of which we only report a small part. Table 2 shows the expected remaining lifetimes at age 65 . The calculations from period tables can be interpreted as the expected remaining lifetime of a contemporary 65-year-old if there was no mortality improvement for his cohort in the future. The difference between two row entries thus yields the effect of the trend function for his cohort. Differences between column entries show the effect of switching from the general to the insured population.

A few critical notes seem necessary regarding these mortality tables. First, one can always dispute the validity of past time trends for predicting future mortality improvements. Another approach would be to model expected medical change and simulate its impact on expected future mortality. ${ }^{12}$ We stick to the standard approach of the DAV because it seems

12 For example, GE Frankona Re bases its reinsurance products for annuities on an approach like this. See GE Frankona Re (2000). 
Table 2:

Expected remaining lifetime

\begin{tabular}{lcccc}
\hline & $\begin{array}{c}\text { Male } \\
\text { population }\end{array}$ & $\begin{array}{c}\text { Male } \\
\text { insured }\end{array}$ & $\begin{array}{c}\text { Female } \\
\text { population }\end{array}$ & $\begin{array}{c}\text { Female } \\
\text { insured }\end{array}$ \\
\hline $\begin{array}{l}\text { Period table for 2003, beginning at } \\
\text { age 65 }\end{array}$ & 16.0 & 18.6 & 19.9 & 22.3 \\
\begin{tabular}{l} 
Cohort aged 65 in 2003 \\
\hline
\end{tabular} & 16.9 & 19.6 & 21.3 & 24.1 \\
\hline
\end{tabular}

Note: Own calculation based on tables provided in Schmithals and Schütz (1995).

reasonable in an international perspective. ${ }^{13}$ The way mortality differences between the general population and annuitants are constructed does not make sense for our purposes. This issue arises because the sample size of insured persons is very small, having a minimum of about 20 observed deaths for females aged 60 to 65 . The resulting relative mortality of insured women aged 60 is 110 per cent compared to 47 per cent at the age of 62 . Clearly, this does not make sense. Schmithals and Schütz (1995) resolve this issue by assuming the relative mortality of this group to be 40 per cent lower for insured persons relative to the general population. While being sufficiently conservative in order to calculate premiums, this approach does not consistently estimate the relative mortality of insured persons. Lacking better data we use these tables anyway. Collecting adequate data on annuitant mortality will be necessary. Therefore, our results for the annuitant population should be seen as an orientation regarding only the magnitude of the selection effects. A more serious problem stems from the lack of data on mortality beyond age 89 . As explained above, the 2001 pension reform incorporates the possibility of programmed withdrawals and deferred annuitization at age 85 . Current data are clearly not sufficient for calculating fairly priced life annuities in this group.

\section{The money's worth of individual life annuities}

In this section we apply the methodology developed by Mitchell et al. (1999) to determine the load factors in the German market, looking at single premium immediate life annuities as described in section 3. To get an idea of the magnitude of the monthly payouts, we first present their averages, maxima, and minima per $€ 1,000$ premium in Tables 3 and $4 .{ }^{14}$ Reported results are from samples of 17 to 61 firms, because not every firm offers the whole range of contract specifications. ${ }^{15}$ Consistent with international findings, ${ }^{16}$ we discover considerable price heterogeneity among firms. Correlations between profit-sharing rates and guaranteed payouts are positive in the range from 0.25 to 0.3 . This means that on average there is no trade-off between the two. If risk aversion varies across consumers, this might have been a reason for payout heterogeneity. Had there been a trade-off, a highly risk

\footnotetext{
13 See McCarthy and Mitchell (2000).

14 All our calculations are based on an initial premium of $€ 100,000$. Contrary to our expectations based on administration loads, increasing this value produces a slight decrease in the payout ratio and vice versa.

15 For our purposes sample size does not matter since we are only interested in the availability of products.

16 See Mitchell and McCarthy (2002) for the U.S., James and Vittas (2001) for the U.K., Australia, and Canada.
} 
Table 3:

Payouts per $€ 1,000$ premium - men

\begin{tabular}{|c|c|c|c|c|c|}
\hline & & $\begin{array}{r}\text { No peric } \\
\text { an }\end{array}$ & $\begin{array}{l}\text { d-certain } \\
\text { uity }\end{array}$ & $\begin{array}{r}\text { Ten years } p \\
\text { anı }\end{array}$ & $\begin{array}{l}\text { riod-certain } \\
\text { uity }\end{array}$ \\
\hline & & $\begin{array}{c}\text { Guaranteed } \\
\text { part }\end{array}$ & $\begin{array}{c}\text { Constant } \\
\text { participation } \\
\text { scheme }\end{array}$ & $\begin{array}{c}\text { Guaranteed } \\
\text { part }\end{array}$ & $\begin{array}{c}\text { Constant } \\
\text { participation } \\
\text { scheme }\end{array}$ \\
\hline & Average & 4.84 & 5.72 & 4.73 & 5.55 \\
\hline 60 & Lowest & 4.72 & 4.73 & 4.50 & 4.64 \\
\hline & Highest & 4.99 & 6.33 & 4.90 & 6.19 \\
\hline & Average & 5.51 & 6.43 & 5.30 & 6.07 \\
\hline 65 & Lowest & 5.38 & 5.45 & 5.04 & 5.25 \\
\hline & Highest & 5.71 & 7.00 & 5.50 & 6.75 \\
\hline & Average & 6.68 & 7.59 & 6.17 & 6.96 \\
\hline 70 & Lowest & 6.47 & 6.47 & 5.86 & 6.02 \\
\hline & Highest & 6.90 & 8.18 & 6.39 & 7.54 \\
\hline
\end{tabular}

Note: Annuity payouts as provided in LV-Win by Morgen \& Morgen GmbH.

Calculations are based on an initial premium of $€ 100,000$ on a single premium immediate life annuity.

Table 4:

Payouts per $€ 1,000$ premium - women

\begin{tabular}{|c|c|c|c|c|c|}
\hline & & \multicolumn{2}{|c|}{$\begin{array}{l}\text { No period-certain } \\
\text { annuity }\end{array}$} & \multicolumn{2}{|c|}{$\begin{array}{c}\text { Ten years period certain } \\
\text { annuity }\end{array}$} \\
\hline & & $\begin{array}{c}\text { Guaranteed } \\
\text { part }\end{array}$ & $\begin{array}{c}\text { Constant } \\
\text { participation } \\
\text { scheme }\end{array}$ & $\begin{array}{c}\text { Guaranteed } \\
\text { part }\end{array}$ & $\begin{array}{c}\text { Constant } \\
\text { participation } \\
\text { scheme }\end{array}$ \\
\hline \multirow{4}{*}{60} & Average & 4.27 & 5.18 & 4.23 & 5.06 \\
\hline & Lowest & 4.17 & 4.19 & 4.04 & 4.16 \\
\hline & Highest & 4.42 & 5.75 & 4.39 & 5.70 \\
\hline & Average & 4.91 & 5.79 & 4.82 & 5.62 \\
\hline \multirow[t]{3}{*}{65} & Lowest & 4.74 & 4.74 & 4.59 & 4.67 \\
\hline & Highest & 5.08 & 6.35 & 5.00 & 6.25 \\
\hline & Average & 5.69 & 6.57 & 5.49 & 6.31 \\
\hline \multirow[t]{2}{*}{70} & Lowest & 5.54 & 5.54 & 5.22 & 5.36 \\
\hline & Highest & 5.89 & 7.12 & 5.70 & 6.88 \\
\hline
\end{tabular}

Note: Annuity payouts as provided in LV-Win by Morgen \& Morgen GmbH. Calculations are based on an initial premium of $€ 100,000$ on a single premium immediate life annuity. 
averse consumer might have chosen a contract with high guaranteed payments and less important participating components, the opposite being true for consumers with lower risk aversion. Examining the link between life annuity payouts and the rating of providers, we also detect some positive correlation. Thus, there is no risk premium implicit in the contracts but pricing seems to depend on factors unobservable to us.

Due to differential mortality, average payouts increase with the entry age and payouts for men are considerably higher than for women at each age. Surplus payouts are almost equal across age and sex groups on an individual contract level, suggesting that they only depend on the initial premium. Thus the variable part of the life annuity is more important for women than for men as they face a lower guaranteed payout. This is also true for younger persons compared to older ones. Findings on period life annuities are not surprising either. We only report values for the ten-year period, which yields lower payouts than a contract without such an attribute. The difference in payouts between regular and period life annuities increases with the entry age because of increasing mortality.

\section{The money's worth methodology}

To illustrate loading charges we calculate the Money's Worth Ratio ("MWR") which is defined as the expected discounted value of future payouts from the insurance company per euro of premium. All monthly benefit payments are multiplied by the probability of reaching the corresponding month of life (i.e. the probability of receiving this payment), discounted, summed up and divided by the initial premium:

$$
\operatorname{MWR}=\frac{1}{\text { Premium }} \cdot \sum_{t=1}^{\mathrm{T}} \frac{\mathrm{p}_{\mathrm{t}} \cdot \mathrm{A}_{\mathrm{t}}}{\left(1+\mathrm{i}_{\mathrm{t}}\right)^{\mathrm{t}}}
$$

At this point three parameters are to be determined: the interest rate for a t-month investment, $i_{t}$, the survival probability up to period $t, p_{t}$, and monthly payouts, $A_{t}$. Regarding the mortality assumptions, we use the tables discussed in the preceding section. ${ }^{17}$ To obtain monthly survival probabilities, we calculate the geometric mean of annual values. This amounts to assuming constant probabilities within years of life. Second, to discount future benefits, we use short-term euro money-market rates and the yields of German government bonds ("Staatsanleihen") for maturities of one to 30 years. The latest maturity on the German treasury market is 26.8 years. After this period we update this interest rate into the future. Last and most important are the insurance payouts. We calculate MWRs for the guaranteed nominal life annuity on its own, and for the two polar participation schemes. The corresponding assumptions are described in detail in the following paragraphs, and a comparative statistical analysis follows at the end of this section. Finally, we incorporate guaranteed payment periods in the analysis. This amounts to assuming a survival probability of one during the period of guaranteed payouts, afterwards the same formulae apply as in the simple case. We only report results for ten-year period period life annuities because MWRs do not vary substantially across different periods.

17 For readers who have skipped this section, there is one table for the general population and another one for insured persons with lower mortality rates. This is due to adverse selection: people with short remaining life expectancies buy immediate annuities much less frequently. 


\section{Discussion of the discount rate}

A major determinant of the MWR is the discount rate which has to reflect an alternative investment with similar risks attached to it. In the case of pure nominal life annuities, this risk is restricted to the insolvency risk of the life annuity provider. This led researchers in other countries to use the corporate bond yields as the discount rates. ${ }^{18}$ We ignore this risk because of the strong regulatory framework in Germany. Even without default risk, German life annuities bear some investment risk for the participating part. Using government yields will overstate the MWR if there is no risk adjustment. However, applying yields of the Markovitz market portfolio will overestimate the attached risk. As the product profile is unique, an adequate rate simply does not exist. A look at the low historical volatility of net investment returns on a book value basis of life insurers favours the use of government yields. ${ }^{19}$ This procedure is disputable and the reader not comfortable with it is referred to the comparative statistical analysis.

\section{Results for Germany}

Consider the first column of Table 5. It contains MWRs only for the guaranteed nominal life annuity assuming zero participation in all periods. This is clearly a drastic assumption, but it provides some insight because the insurer bears investment and mortality risk only up to this point. The first entry shows the MWR for 60 -year-old males, assuming population mortality. Its value of 0.76 appears to be rather low, but apart from the interest rate, assumptions are as conservative as possible. Results for ages 60 and 70 are similar. Looking at the outcomes for annuitants, we find a selection effect which raises the MWR by 0.07 to 0.09 points. This is about the magnitude encountered in international comparisons. ${ }^{20}$ Nevertheless it should be interpreted with caution due to the problems associated with the corresponding mortality table.

For the second column we use 2003 payouts of contracts with the constant participation scheme and simply update them into all future periods. We will return to the plausibility of this assumption later. Ratios rise to 0.89 and more. The increase is most pronounced for 60year-olds because, as noted earlier, the absolute value of the participation payment only depends on initial premiums. This group has the highest remaining life expectancy. The selection effect rises proportionally compared to the first column. For annuitants the MWR approaches unity.

In order to obtain MWRs for the escalating participation scheme we use the same growth rates of the annuities for all periods as reported in our database for 2003 for each insurer. MWRs are slightly lower than for the constant participation scheme. In this case the selection effect becomes more pronounced because high benefits in late periods are weighted stronger due to lower mortality among annuitants.

With regard to period annuities, we do not expect notable changes of the MWR for the annuitants. Turning the life annuity into a certain payment during a ten-year period should be reflected in a reduction of payouts which is based on annuitant mortality. Our results confirm this expectation. Correspondingly, MWRs for the general population rise slightly by

\footnotetext{
18 See Mitchell and McCarthy (2002) for a good discussion.

19 This implies using portfolio volatility as perceived by the consumer as risk measure.

20 An overview is given in Mitchell and McCarthy (2002).
} 
Table 5:

Money's worth ratios for men

\begin{tabular}{|c|c|c|c|c|c|c|c|}
\hline \multicolumn{2}{|r|}{ Men } & \multicolumn{3}{|c|}{ No guaranteed payment period } & \multicolumn{3}{|c|}{ Ten years guaranteed payment period } \\
\hline Age & $\begin{array}{c}\text { Mortality } \\
\text { table }\end{array}$ & $\begin{array}{c}\text { Only } \\
\text { guaranteed } \\
\text { part }\end{array}$ & $\begin{array}{c}\text { Constant } \\
\text { participation } \\
\text { scheme }\end{array}$ & $\begin{array}{c}\text { Escalating } \\
\text { participation } \\
\text { scheme* }\end{array}$ & $\begin{array}{c}\text { Only } \\
\text { guaranteed } \\
\text { part }\end{array}$ & $\begin{array}{c}\text { Constant } \\
\text { participation } \\
\text { scheme }\end{array}$ & $\begin{array}{c}\text { Escalating } \\
\text { participation } \\
\text { scheme }^{* *}\end{array}$ \\
\hline \multirow[t]{2}{*}{60} & Population & 0.763 & 0.902 & 0.886 & 0.780 & 0.915 & 0.894 \\
\hline & Annuitants & 0.833 & 0.985 & 0.981 & 0.835 & 0.980 & 0.971 \\
\hline \multirow[t]{2}{*}{65} & Population & 0.760 & 0.886 & 0.864 & 0.788 & 0.902 & 0.885 \\
\hline & Annuitants & 0.840 & 0.980 & 0.968 & 0.846 & 0.969 & 0.963 \\
\hline \multirow[t]{2}{*}{70} & Population & 0.780 & 0.887 & 0.868 & 0.817 & 0.921 & 0.900 \\
\hline & Annuitants & 0.872 & 0.990 & 0.982 & 0.876 & 0.988 & 0.976 \\
\hline
\end{tabular}

* Average growth rate: 1.55 per cent. ** Average growth rate: 1.45 per cent.

Note: Each entry shows the money's worth ratio. All calculations use the all-company sample average annuity payouts. Samples differ by type of contract, which is why average growth rates may also differ. 
Table 6:

Money's worth ratios for women

\begin{tabular}{|c|c|c|c|c|c|c|c|}
\hline \multicolumn{2}{|r|}{ Women } & \multicolumn{3}{|c|}{ No guaranteed payment period } & \multicolumn{3}{|c|}{ Ten years guaranteed payment period } \\
\hline Age & $\begin{array}{c}\text { Mortality } \\
\text { table }\end{array}$ & $\begin{array}{c}\text { Only } \\
\text { guaranteed } \\
\text { part }\end{array}$ & $\begin{array}{c}\text { Constant } \\
\text { participation } \\
\text { scheme }\end{array}$ & $\begin{array}{c}\text { Escalating } \\
\text { participation } \\
\text { scheme* }\end{array}$ & $\begin{array}{c}\text { Only } \\
\text { guaranteed } \\
\text { part }\end{array}$ & $\begin{array}{c}\text { Constant } \\
\text { participation } \\
\text { scheme }\end{array}$ & $\begin{array}{c}\text { Escalating } \\
\text { participation } \\
\text { scheme** }\end{array}$ \\
\hline \multirow[t]{2}{*}{60} & Population & 0.776 & 0.942 & 0.922 & 0.782 & 0.935 & 0.917 \\
\hline & Annuitants & 0.826 & 1.003 & 0.995 & 0.827 & 0.988 & 0.982 \\
\hline \multirow[t]{2}{*}{65} & Population & 0.795 & 0.938 & 0.921 & 0.805 & 0.940 & 0.923 \\
\hline & Annuitants & 0.857 & 1.012 & 1.008 & 0.858 & 1.001 & 0.997 \\
\hline \multirow[t]{2}{*}{70} & Population & 0.795 & 0.918 & 0.900 & 0.814 & 0.936 & 0.912 \\
\hline & Annuitants & 0.870 & 1.005 & 0.999 & 0.873 & 1.004 & 0.992 \\
\hline
\end{tabular}

* Average growth rate: 1.55 per cent. ** Average growth rate: 1.45 per cent.

Note: Each entry shows the money's worth ratio. All calculations use the all-company sample average annuity payouts. Samples differ by type of contract, which is why average growth rates may also differ. 
0.01 to 0.04 points because setting mortality to zero over ten years results in a larger difference for this group. Hence, the selection effect can be attenuated by including a guaranteed payment period.

Results for women are reported in Table 6. MWRs are higher in most cases, around 0.78 for the guaranteed life annuity in the general population. The selection effect seems to be less important than for males, ranging from 0.05 to 0.075 in the first column. Incorporating any participation component produces stronger increases in the MWR than in the case of males which is due to lower female mortality. Again, the participation component depends only on the initial premium, not on sex or age. Nearly all values including participation payments exceed unity. Conclusions regarding period life annuities are the same as for males.

\section{Comparative statistics}

Our results depend heavily on the assumptions on interest and profit sharing rates. Up to now we assumed values given today which need not be valid in the future. In this section we explore alternative scenarios and relate them to past experiences. We consider increases in either one or both rates. Similar results are obtained for corresponding decreases, thus we do not report them.

Tables 7 and 8 show some results if 100 or 200 basis points are added to either the annual interest or the profit-sharing rate, or both. Raising the interest rate by 100 basis points produces drops of 0.05 to 0.07 in MWRs of the guaranteed part (see the first column in each panel II). The effect gets weaker when increasing the entry age, which is also true for relative changes. These are nearly equal in all three columns. An increase of 100 basis points in the interest rate causes the money's worth to fall by 6.3 per cent to 8.3 per cent. The effect is strongest for women aged 60 and least pronounced for 70-year-old men. It declines in the magnitude of the basis points added to the interest rate (see panel V). These figures show how important interest rate assumptions are for the MWR.

When varying the profit-sharing rates, we only consider changes in the annuities' growth rates in the escalating scheme. We did not find a reasonable way to model the impact of changes in profit-sharing rates on benefits in the constant participation scheme. The relative changes are slightly larger in absolute value than in the case of the interest rate. Adding 100 basis points to the profit-sharing rate in each period yields a rise in the MWR of 7.8 per cent to 13.5 per cent. The large range stems from mortality differences and the calculation of the participation component. As expected, it is highest for the group with the lowest mortality rate which are female annuitants aged 60. A 70-year-old man belonging to the general population profits the least from such a rise. ${ }^{21}$

Increasing both rates by 100 basis points at the same time yields MWRs similar to the ones resulting from our original assumptions (see panel IV in each table). If they are increased by 200 basis points each, the profit-sharing rate effect dominates and causes higher MWRs.

The assumptions which led to our original results under either the constant or the escalating participation scheme seem most plausible to us. The profit-sharing rates we use appear sufficiently conservative, even though capital market situations might become more

21 The gains would be closer together in the case of constant participation. See the above discussion of the selection effect in the different participation schemes. 
Table 7:

Comparative statistics - men, no guaranteed payment period

\begin{tabular}{|c|c|c|c|c|c|c|c|c|c|}
\hline \multicolumn{5}{|c|}{ Panel I } & \multicolumn{5}{|c|}{ Panel II } \\
\hline \multicolumn{2}{|l|}{ Age } & \multirow{2}{*}{$\begin{array}{c}\begin{array}{c}\text { Only } \\
\text { guaranteed } \\
\text { part }\end{array} \\
0.763 \\
\end{array}$} & \multirow{2}{*}{$\begin{array}{c}\begin{array}{c}\text { Constant } \\
\text { participation } \\
\text { scheme }\end{array} \\
0.902 \\
\end{array}$} & \multirow{2}{*}{$\begin{array}{c}\begin{array}{c}\text { Escalating } \\
\text { participation } \\
\text { scheme }\end{array} \\
0.886\end{array}$} & \multicolumn{2}{|c|}{ Age } & \multirow{2}{*}{$\begin{array}{c}\begin{array}{c}\text { Only } \\
\text { guaranteed } \\
\text { part }\end{array} \\
0.705\end{array}$} & \multirow{2}{*}{$\begin{array}{c}\begin{array}{c}\text { Constant } \\
\text { participation } \\
\text { scheme }\end{array} \\
0.834\end{array}$} & \multirow{2}{*}{$\begin{array}{c}\begin{array}{c}\text { Escalating } \\
\text { participation } \\
\text { scheme }\end{array} \\
0.815\end{array}$} \\
\hline$\overline{60}$ & Population & & & & & Population & & & \\
\hline & Annuitants & 0.833 & 0.985 & 0.981 & & Annuitants & 0.769 & 0.909 & 0.901 \\
\hline \multirow[t]{2}{*}{65} & Population & 0.760 & 0.886 & 0.864 & & Population & 0.706 & 0.823 & 0.798 \\
\hline & Annuitants & 0.840 & 0.980 & 0.968 & & Annuitants & 0.778 & 0.907 & 0.891 \\
\hline \multirow[t]{4}{*}{70} & Population & 0.780 & 0.887 & 0.868 & 70 & Population & 0.731 & 0.830 & 0.809 \\
\hline & Annuitants & 0.872 & 0.990 & 0.982 & & Annuitants & 0.812 & 0.923 & 0.911 \\
\hline & \multicolumn{3}{|c|}{ Basis points added to interest rate: } & 0 & \multicolumn{4}{|c|}{ Basis points added to interest rate: } & 100 \\
\hline & \multicolumn{3}{|c|}{ Basis points added to profit-sharing rates: } & 0 & \multicolumn{4}{|c|}{ Basis points added to profit-sharing rates: } & 0 \\
\hline
\end{tabular}




\begin{tabular}{|c|c|c|c|c|c|c|c|c|c|}
\hline \multicolumn{5}{|c|}{ Panel III } & \multicolumn{5}{|c|}{ Panel IV } \\
\hline \multicolumn{2}{|l|}{ Age } & \multirow{2}{*}{$\begin{array}{c}\text { Only } \\
\text { guaranteed } \\
\text { part }\end{array}$} & \multirow{2}{*}{$\begin{array}{c}\begin{array}{c}\text { Constant } \\
\text { participation } \\
\text { scheme }\end{array} \\
-\end{array}$} & \multirow{2}{*}{$\begin{array}{c}\begin{array}{c}\text { Escalating } \\
\text { participation } \\
\text { scheme }\end{array} \\
0.980\end{array}$} & \multicolumn{2}{|c|}{ Age } & \multirow{2}{*}{$\begin{array}{c}\text { Only } \\
\text { guaranteed } \\
\text { part }\end{array}$} & \multirow{2}{*}{$\begin{array}{c}\begin{array}{c}\text { Constant } \\
\text { participation } \\
\text { scheme }\end{array} \\
-\end{array}$} & \multirow{2}{*}{$\begin{array}{c}\begin{array}{c}\text { Escalating } \\
\text { participation } \\
\text { scheme }\end{array} \\
0.899\end{array}$} \\
\hline$\overline{60}$ & Population & & & & & Population & & & \\
\hline & Annuitants & - & - & 1.096 & & Annuitants & - & - & 1.005 \\
\hline \multirow[t]{2}{*}{65} & Population & - & - & 0.941 & 65 & Population & - & - & 0.867 \\
\hline & Annuitants & - & - & 1.064 & & Annuitants & - & - & 0.977 \\
\hline \multirow[t]{4}{*}{70} & Population & - & - & 0.931 & 70 & Population & - & - & 0.866 \\
\hline & Annuitants & - & - & 1.063 & & Annuitants & - & - & 0.983 \\
\hline & Basis points & added to intere & st rate: & 0 & & Basis points & added to intere & st rate: & 100 \\
\hline & Basis points & added to profit & sharing rates: & 100 & & Basis points & added to profit & -sharing rates: & 100 \\
\hline
\end{tabular}


Table 7:

Continued

\begin{tabular}{|c|c|c|c|c|c|c|c|c|c|}
\hline \multicolumn{5}{|c|}{ Panel V } & \multicolumn{5}{|c|}{ Panel VI } \\
\hline \multicolumn{2}{|c|}{ Age } & \multirow{2}{*}{$\begin{array}{c}\begin{array}{c}\text { Only } \\
\text { guaranteed } \\
\text { part }\end{array} \\
0.654\end{array}$} & \multirow{2}{*}{$\begin{array}{c}\begin{array}{c}\text { Constant } \\
\text { participation } \\
\text { scheme }\end{array} \\
0.774\end{array}$} & \multirow{2}{*}{$\begin{array}{c}\begin{array}{c}\text { Escalating } \\
\text { participation } \\
\text { scheme }\end{array} \\
0.753\end{array}$} & \multicolumn{2}{|c|}{ Age } & \multirow{2}{*}{$\begin{array}{c}\begin{array}{c}\text { Only } \\
\text { guaranteed } \\
\text { part }\end{array} \\
-\end{array}$} & \multirow{2}{*}{$\begin{array}{c}\begin{array}{c}\text { Constant } \\
\text { participation } \\
\text { scheme }\end{array} \\
-\end{array}$} & \multirow{2}{*}{$\begin{array}{c}\begin{array}{c}\text { Escalating } \\
\text { participation } \\
\text { scheme }\end{array} \\
0.917\end{array}$} \\
\hline$\overline{60}$ & Population & & & & 60 & Population & & & \\
\hline & Annuitants & 0.712 & 0.842 & 0.832 & & Annuitants & - & - & 1.037 \\
\hline \multirow[t]{2}{*}{65} & Population & 0.658 & 0.768 & 0.741 & 65 & Population & - & - & 0.872 \\
\hline & Annuitants & 0.723 & 0.843 & 0.825 & & Annuitants & - & - & 0.991 \\
\hline \multirow[t]{4}{*}{70} & Population & 0.687 & 0.780 & 0.758 & 70 & Population & - & - & 0.865 \\
\hline & Annuitants & 0.760 & 0.863 & 0.848 & & Annuitants & - & - & 0.986 \\
\hline & \multicolumn{3}{|c|}{ Basis points added to interest rate: } & 200 & \multicolumn{4}{|c|}{ Basis points added to interest rate: } & 200 \\
\hline & \multicolumn{3}{|c|}{ Basis points added to profit-sharing rates: } & 0 & \multicolumn{4}{|c|}{ Basis points added to profit-sharing rates: } & 200 \\
\hline
\end{tabular}

Note: Each entry shows the money's worth ratio using the same samples as before. Either a parallel shift is applied to the interest rate for each period and/or the profit-sharing rate is increased in the same fashion. 
Table 8:

Comparative statistics - women, no guaranteed payment period

Panel II

\section{Panel I}

\begin{tabular}{|c|c|c|c|c|}
\hline Age & & $\begin{array}{c}\text { Only } \\
\text { guaranteed } \\
\text { part }\end{array}$ & $\begin{array}{c}\text { Constant } \\
\text { participation } \\
\text { scheme }\end{array}$ & $\begin{array}{c}\text { Escalating } \\
\text { participation } \\
\text { scheme }\end{array}$ \\
\hline \multirow[t]{2}{*}{60} & Population & 0.776 & 0.942 & 0.922 \\
\hline & Annuitants & 0.826 & 1.003 & 0.995 \\
\hline \multirow[t]{2}{*}{65} & Population & 0.795 & 0.938 & 0.921 \\
\hline & Annuitants & 0.857 & 1.012 & 1.008 \\
\hline \multirow[t]{4}{*}{70} & Population & 0.795 & 0.918 & 0.900 \\
\hline & Annuitants & 0.870 & 1.005 & 0.999 \\
\hline & \multicolumn{3}{|c|}{ Basis points added to interest rate: } & 0 \\
\hline & \multicolumn{3}{|c|}{ Basis points added to profit-sharing rates: } & 0 \\
\hline
\end{tabular}

Only Constant Escalating guaranteed participation participation

Age part scheme scheme

60 Population $\quad 0.715 \quad 0.868 \quad 0.846$

$\begin{array}{llll}\text { Annuitants } & 0.761 & 0.924 & 0.914\end{array}$

65 Population

0.733

0.866

0.846

$\begin{array}{llll}\text { Annuitants } & 0.790 & 0.933 & 0.925\end{array}$

70 Population

0.738

0.805

0.853

0.832

Annuitants

Basis points added to interest rate:

0.930

Basis points added to profit-sharing rates: 
Table 8:

Continued

\begin{tabular}{|c|c|c|c|c|c|c|c|c|c|}
\hline \multicolumn{5}{|c|}{ Panel III } & \multicolumn{5}{|c|}{ Panel IV } \\
\hline \multicolumn{2}{|c|}{ Age } & \multirow{2}{*}{$\begin{array}{c}\begin{array}{c}\text { Only } \\
\text { guaranteed } \\
\text { part }\end{array} \\
-\end{array}$} & \multirow{2}{*}{$\begin{array}{c}\begin{array}{c}\text { Constant } \\
\text { participation } \\
\text { scheme }\end{array} \\
-\end{array}$} & \multirow{2}{*}{$\begin{array}{c}\begin{array}{c}\text { Escalating } \\
\text { participation } \\
\text { scheme }\end{array} \\
1.036\end{array}$} & \multicolumn{2}{|c|}{ Age } & \multirow{2}{*}{$\begin{array}{c}\begin{array}{c}\text { Only } \\
\text { guaranteed } \\
\text { part }\end{array} \\
-\end{array}$} & \multirow{2}{*}{$\begin{array}{c}\begin{array}{c}\text { Constant } \\
\text { participation } \\
\text { scheme }\end{array} \\
-\end{array}$} & \multirow{2}{*}{$\begin{array}{c}\begin{array}{c}\text { Escalating } \\
\text { participation } \\
\text { scheme }\end{array} \\
0.948\end{array}$} \\
\hline 60 & Population & & & & 60 & Population & & & \\
\hline & Annuitants & - & - & 1.130 & & Annuitants & - & - & 1.036 \\
\hline \multirow[t]{2}{*}{65} & Population & - & - & 1.018 & 65 & Population & - & - & 0.932 \\
\hline & Annuitants & - & - & 1.125 & & Annuitants & - & - & 1.030 \\
\hline \multirow[t]{4}{*}{70} & Population & - & - & 0.978 & 70 & Population & - & - & 0.901 \\
\hline & Annuitants & - & - & 1.096 & & Annuitants & - & - & 1.006 \\
\hline & Basis points & dded to intere & it rate: & 0 & & Basis point & added to intere & st rate: & 100 \\
\hline & Basis points & dded to profit & sharing rates: & 100 & & Basis point & added to profit & sharing rates: & 100 \\
\hline
\end{tabular}




\begin{tabular}{|c|c|c|c|c|c|c|c|c|c|}
\hline \multicolumn{5}{|c|}{ Panel V } & \multicolumn{5}{|c|}{ Panel VI } \\
\hline \multicolumn{2}{|c|}{ Age } & \multirow{2}{*}{$\begin{array}{c}\begin{array}{c}\text { Only } \\
\text { guaranteed } \\
\text { part }\end{array} \\
0.662 \\
\end{array}$} & \multirow{2}{*}{$\begin{array}{c}\begin{array}{c}\text { Constant } \\
\text { participation } \\
\text { scheme }\end{array} \\
0.803 \\
\end{array}$} & \multirow{2}{*}{$\begin{array}{c}\begin{array}{c}\text { Escalating } \\
\text { participation } \\
\text { scheme }\end{array} \\
0.780\end{array}$} & \multicolumn{2}{|c|}{ Age } & \multirow{2}{*}{$\begin{array}{c}\begin{array}{c}\text { Only } \\
\text { guaranteed } \\
\text { part }\end{array} \\
-\end{array}$} & \multirow{2}{*}{$\begin{array}{c}\text { Constant } \\
\text { participation } \\
\text { scheme }\end{array}$} & \multirow{2}{*}{$\begin{array}{c}\begin{array}{c}\text { Escalating } \\
\text { participation } \\
\text { scheme }\end{array} \\
0.984\end{array}$} \\
\hline 60 & Population & & & & & Population & & & \\
\hline & Annuitants & 0.705 & 0.855 & 0.844 & & Annuitants & - & - & 1.093 \\
\hline \multirow[t]{2}{*}{65} & Population & 0.679 & 0.803 & 0.780 & 65 & Population & - & - & 0.946 \\
\hline & Annuitants & 0.731 & 0.864 & 0.853 & & Annuitants & - & - & 1.060 \\
\hline \multirow[t]{4}{*}{70} & Population & 0.688 & 0.795 & 0.772 & 70 & Population & - & - & 0.903 \\
\hline & Annuitants & 0.748 & 0.864 & 0.851 & & Annuitants & - & - & 1.017 \\
\hline & \multicolumn{3}{|c|}{ Basis points added to interest rate: } & 200 & \multicolumn{4}{|c|}{ Basis points added to interest rate: } & 200 \\
\hline & \multicolumn{3}{|c|}{ Basis points added to profit-sharing rates: } & 0 & & Basis points & added to profit & sharing rates: & 200 \\
\hline
\end{tabular}

Note: Each entry shows the money's worth ratio using the same samples as before. Either a parallel shift is applied to the interest rate for each period and/or the profit-sharing rate is increased in the same fashion. 
difficult in the short run. Another assumption one may want to criticize is the interest rate level, which is also low from a historical perspective. This might yield MWRs that are too high. However, if they were to increase, we would suspect a positive correlation of interest and profit-sharing rates. ${ }^{22}$ In this case, either scenario IV or VI might apply and results do not change substantially.

\section{International comparisons}

Our results fit well with international findings as compiled in Mitchell and McCarthy (2002) from different sources. We report them in Table 9. MWRs based on our preferred assumptions for both annuitant and general populations are comparable to those estimated for the U.K., Australia and Italy, while being slightly lower than Canada and higher than the U.S. Nevertheless, it should be noted that these values are estimates for guaranteed nominal life annuities, while our analysis is based on participating life annuities. This does not imply direct utility consequences if consumers are willing to bear some risk. After all, there is the possibility to gain more through the participation component, which is not present in pure guaranteed life annuities. Estimates for the MWR of participating life annuities are available for Switzerland. They are remarkably high, exceeding unity for almost all subgroups of the population. In our understanding of the original paper by James and Vittas (2001), these are based on rather optimistic assumptions on the participation component. Results are comparable to those reported in the third panels of Tables 7 and 8 , which reflect the scenario of a few years ago.

Table 9:

International MWRs - 65-year-old men

\begin{tabular}{|c|c|c|c|c|c|c|c|}
\hline & Germany & U.K. & Australia & Canada & Switzerland & U.S. & Italy \\
\hline Population & 0.887 & 0.897 & 0.914 & 0.925 & 0.965 & 0.814 & $\begin{array}{c}\text { not } \\
\text { available }\end{array}$ \\
\hline Annuitants & 0.980 & 0.966 & 0.986 & 1.014 & 1.169 & 0.927 & 0.958 \\
\hline \multicolumn{8}{|c|}{ International MWRs - 65-year-old women } \\
\hline & Germany & U.K. & Australia & Canada & Switzerland & U.S. & Italy \\
\hline Population & 0.939 & 0.910 & 0.910 & 0.937 & 1.029 & 0.852 & not \\
\hline Annuitants & 1.013 & 0.957 & 0.970 & 1.015 & 1.152 & 0.927 & 0.965 \\
\hline
\end{tabular}

Note: Results for Germany are taken from our own calculations. MWRs for other countries stem from the compilation given in Mitchell and McCarthy (2002) and from James and Vittas (2001).

\section{The insurance value of life annuities}

We use the results from Mitchell et al. (1999) to illustrate the utility value for a CRRA utility function with a unity risk aversion parameter. This reflects a relatively low risk 
aversion. They assume stochastic inflation with a mean of 3.2 per cent and a pre-existing real life annuity amounting to 50 per cent of total wealth at the age of 65 , e.g. claims from public old age insurance. For different values of the interest rate and the individual time discount rate, they obtain critical MWR values of about 0.75 . This is to be interpreted as follows: an individual with this utility function who already owns a real life annuity will attach a positive utility value to an additional nominal life annuity if the loading charges do not exceed 25 per cent. Comparing this result to Tables 7 and 8 , we find that he will buy an additional life annuity in nearly all of the scenarios, even if only considering the guaranteed part of the annuity.

\section{Summary and conclusions}

Our findings thus far came as a positive surprise to us. Money's worth ratios in Germany are comparable to international ones despite the small market size. Consumers can choose among many different contract specifications, although we are missing offers of real life annuities and offers for people older than 70. The decline of benefits from the public old age insurance scheme and tax benefits for private retirement saving will lead to an increase in volume. It is not clear, however, what will happen to money's worth ratios if life annuities account for a significant part of insurance companies' revenue in the future. They might increase because of fiercer competition. On the contrary, if companies have some market power, MWRs could decrease because life annuities have to account for a larger revenue share.

The results have clear policy implications. Loading charges represent the appropriate measure for the prices of life annuities. They are similar for both sexes. Arguments in favour of unisex policies, as currently proposed by the European Commission, are based on the monthly payouts contained in Tables 3 and 4 . They consider the fact that figures for women are lower than for men to be a sign of discrimination. However, this reasoning is flawed because it does not look at the expected payment period. The introduction of mandatory unisex policies would necessarily cause a gap between MWRs for men and women, possibly even leading to an adverse selection spiral.

Mortality tables will need improvement in order to facilitate sensible pricing of life annuities with an entry age of 85 years which are projected to be a popular withdrawal option for third pillar saving. In our view, a better estimation of the selection effect is desirable.

\section{REFERENCES}

ALBRECHT, P. and MAURER, R., 2002, "Self-Annuitization, Consumption Shortfall in Retirement and Asset Allocation", Journal of Pension Economics and Finance, 1 (3), November, pp. 269-288.

GDV, GESAMTVERBAND DER DEUTSCHEN VERSICHERUNGSWIRTSCHAFT e.V., 2000, Statistical Yearbook of German Insurance. Karlsruhe: Verlag Versicherungswirtschaft.

GDV, GESAMTVERBAND DER DEUTSCHEN VERSICHERUNGSWIRTSCHAFT e.V., 2001, Statistical Yearbook of German Insurance. Karlsruhe: Verlag Versicherungswirtschaft.

GDV, GESAMTVERBAND DER DEUTSCHEN VERSICHERUNGSWIRTSCHAFT e.V., 2002, Statistical Yearbook of German Insurance. Karlsruhe: Verlag Versicherungswirtschaft.

GE FRANKONA RE, 2000, Langlebigkeit und Leibrenten: Die Rückversicherungslösungen der GE Frankona Re. Munich.

JAMES, E. and VITTAS, D., 2001, “Annuities markets in comparative perspective: Do consumers get their money's worth?", in OECD 2000 Private Pensions Conference. Paris: OECD.

McCARTHY, D. and MITCHELL, O., 2001, "Assessing the Impact of Mortality Assumptions on Annuity 
Valuation: Cross-Country Evidence", Pension Research Council Working Paper 2001-3, The Wharton School, University of Pennsylvania.

McCARTHY, D. and MITCHELL, O., 2002, "International Adverse Selection in Life Insurance and Annuities", Pension Research Council Working Paper 2002-8, The Wharton School, University of Pennsylvania.

MITCHELL, O. and McCARTHY, D., 2002, “Annuities for an Ageing World”, NBER Working Paper 9092, National Bureau of Economic Research, Cambridge, MA.

MITCHELL, O., POTERBA, J., WARSHAWSKY, M. and BROWN, J., 1999, "New Evidence on the Money's Worth of Individual Annuities", American Economic Review, December, pp. 1299-1318.

POTERBA, J., 1997, "The History of Annuities in the United States", NBER Working Paper, 6001, National Bureau of Economic Research, Cambridge, MA.

SCHIERENBECK, H. and HÖLSCHER, R., 1998, Bank Assurance (4 ${ }^{\text {th }}$ edn). Stuttgart: Schäffer Poeschel.

SCHMITHALS, B. and SCHÜTZ, E., 1995, "Herleitung der DAV-Sterbetafel 1994 R für Rentenversicherungen”, Blätter der Deutschen Gesellschaft für Versicherungsmathematik, XXII, April, pp. 29-69.

SCHNABEL, R., 2002, "Annuities in Germany before and after the Pension Reform of 2001", CeRP Working Paper 27/02, Centre for Research on Pensions and Welfare Policies, Turin.

WARSHAWSKY, M., 1988, "Private Annuities Markets in the United States", Journal of Risk and Insurance, September, 55(3), pp. 518-528. 